\title{
Removal of heavy metal ions from some wastewater by using different agricultural wastes
}

\author{
Dwidar. E.A**; $;$ Foda, F.A.F ${ }^{*}$ and Abd El-Aleem, I.M* \\ *Faculty of Agri.; Dept., of Biochem.,Benha Univ. Egypt \\ ***.Sc. Agric.Sci(Agric.Biochemistry),Fac.OfAgric,BenhaUniv. Egypt \\ Corresponding author: Enaskh10@Hotmail.Com
}

\begin{abstract}
Industrial wastewaters are deposed into the River Nile without any treatment. High concentrations of some heavy metals i-e $\mathrm{Ni}^{+2}, \mathrm{Cu}^{+2}, \mathrm{Zn}^{+2}, \mathrm{CO}^{+2}$ and $\mathrm{Cd}^{+2}$, promate the growth of gelatinous masses and hence cause industrial and agriculture problems. Polluted water may cause many health problems such as liver and kidney diseases. The aim of the present study is an attempt to removal heavy metals in industrial wastewater. Also, evaluation of some agricultural wastes such as orange peels, banana peels and leaves of date trees as biosorbent to remove the heavy metals which presenting from wastewater such as nickel $\left(\mathrm{Ni}^{+2}\right)$, copper $\left(\mathrm{Cu}^{+2}\right), \mathrm{zinc}\left(\mathrm{Zn}^{+2}\right)$, lead $\left(\mathrm{pb}^{+2}\right)$, cobalt $\left(\mathrm{CO}^{+2}\right)$ and cadmium $\left(\mathrm{Cd}^{+2}\right)$ by using prepared active carbons from the above-mentioned materials of different agricultural wastes in batch adsorption process. Proximate, chemical components of lignocellulosic wastes under investigation were determined. Also, physical and chemical preparation of wastewater and the produced active carbons from different agro-wastes were evaluated. On the other hand, the activated carbons from different agro-wastes were used as biosorbents for removal of some above-mentioned heavy metals before deposing in wastewater.
\end{abstract}

Keywords: Agriculture Wastes; Activated Carbons; Heavy Metals; Adsorption.

\section{Introduction}

Environmental pollution is currently one of the most important issues facing humanity. It was increased exponentially in the past few years and reached alarming levels in terms of its effects on living creatures. Toxic heavy metals are considered as one of the pollutants that have the direct effect on man and animals. Industrial wastewater containing nickel, copper, zinc, lead, cobalt and cadmium, etc, for example, can contaminate River Nile and thus lead to a serious pollution problem (Renge et al., 2012).

Heavy metals in the environmentsuch as water are harmful to human and environment. These heavy metals include elements like cadmium, nickel, lead, copper, zinc, manganese and cobalt etc. The presence of heavy metal results in bioaccumulation and further it can affect the biological and ecological cycles (Kulkarniet al., 2014).

Agricultural wastes and by-products were found to be low cost and alternative adsorbents for the removal of heavy metal ions by adsorption processes. Agricultural wastes are rich in organic contents with a variety of functional groups which can co-operate binding of cations and anions. The other advantages of agricultural wastes like orange peel and banana peel are easily available, non-hazardous and no disposal problems (Lakshmipathyet al., 2015).

Li et al., (2008) used orange peel for the removal of $\mathrm{Cd}^{+2}, \mathrm{Ni}^{+2}, \mathrm{CO}^{+2}$ and $\mathrm{Zn}^{+2}$ ions and they found that protonated orange peels had shown highest loading capacity compared to native peels. Achaka et al., (2009) investigated the efficiency of banana peel as a biosorbent for removal of phenolic compounds from olive mill wastewaters. Banana peel is largely composed of cellulose, pectin, galacturonic acid, hemicellulose, lignin, chlorophyll pigments and other low molecular weight compounds, including limonene. Layla and Ahmed (2010) used wastes of date palm tree leaves to remove heavy metalcations $\left(\mathrm{Cu}^{+2}, \mathrm{Cd}^{+2}\right.$ and $\left.\mathrm{Zn}^{+2}\right)$ from simulated artificial wastewater using batch adsorption process. They found that date palm wastes succeeded to achieve $90 \%$ removal for $\mathrm{Cu}^{+2}$ ions, $57.5 \%$ for $\mathrm{Cd}^{+2}$ ions and $37.5 \%$ for $\mathrm{Zn}^{+2}$ ions within $(60 \mathrm{~min})$ contact time at adsorbent loading ratio of $30 \mathrm{~g} / \mathrm{l}$. Hossain et al., (2012)used agricultural wastes from banana peel to produce bioadsorbent through easy and environmental friendly processes. The characterization results showed that sorbent had very high specific surface area, potential binding sites and functional groups. The optimal conditions for sorbent were found at $\mathrm{pH} 6.5$, sorbent size of less than $75 \mu$, dose of $0.5 \mathrm{~g} / 100 \mathrm{ml}$ and contact time $1 \mathrm{~h}$. MorenoPiraján and Giraldo (2012)found that the activated carbons obtained from orange peel (ACOP) has the ability to retain $\mathrm{Cr}^{+3}, \mathrm{Cd}^{+2}$, and $\mathrm{CO}^{+2}$ metals ions from the aqueous solutions at different concentrations. ACOP has a relatively high adsorption capacity for these heavy metals the quantities adsorbed per gram of (ACOP) at equilibrium were $28.67 \mathrm{mg} / \mathrm{g}$ for $\mathrm{Cd}^{+2} 30.11 \mathrm{mg} / \mathrm{g}$ for $\mathrm{Cr}^{+2}$ and $45.44 \mathrm{mg} \cdot \mathrm{g}-1$ for $\mathrm{CO}^{+2}$.Husoon et al., (2013) used less expensive and much frequently available materials, orange peel and lemon peels to remove copper and lead from industrial wastewater. They found that the peels powder of both orange and lemon showed a higher capacity than fresh and dried pieces where the lemon powder has shown biosorption capacity of $72.5 \%$ and $71.3 \%$ for lead and copper, respectively. While, orange powder had a bio-removal percentage of 
$56.7 \%$ of lead and $34.5 \%$ for copper. Sridhar et al., (2014)found that the percentage of removal of copper and lead from automotive wastewater byusing banana peels were 93.52 and $87.44 \%$, respectively.

Jain (2015)used the various fruits and vegetable peels such as pineapple peels, potato peels, citrus fruits peels, orange peels, pomegranate peels, banana peels and tomato peels for removal of heavy metal. The extent of removal of heavy metals was found to be dependent on sorbent dose, initial concentration, $\mathrm{pH}$ and temperature. Manjuladevi and Oviuaa (2017) studied that activated carbons produced from cucumismelo peel $(\mathrm{CM})$ was used as adsorbent to remove $\mathrm{Cr}^{+6}, \mathrm{Cd}^{+2}, \mathrm{Ni}^{+2}$ and $\mathrm{Pb}^{+2}$ ions from battery industry and electroplating industrial wastewater. The obtained results showed thatthe optimum adsorbent dosage, metal ion concentration and $\mathrm{pH}$ were found to be at $250 \mathrm{mg}, 100 \mathrm{mg} / \mathrm{L}$ and $\mathrm{pH} 3$ to 6 respectively.

The aim of the present works was to remove heavy metals of the industrial wastewater and evaluated of some agricultural by- products as biosorbent to remove the heavy metals of wastewater.

\section{Materials and Methods}

The samples were collected from industrial wastewater in Mubarak Zone (Quesna-Monofeya Governorate) two samples; were collected the first were taken after treatment and the second is before treatment bywater desalination plant.

Activated carbons from different agriculture food wastesthe activated carbons were prepared by following the one step pyrolysis method according to the methods described by Amaya et al., (2007),Zuoet al., (2009) and Sugumaran et al ., (2012).

Chemical composition of agricultural food wastes:-

The moisture content, crude ash, crude fat and crud protein were determined according to method described by A.O.A.C (2010). The total carbohydrateswere determined according to Bernfeld (1955) and Miller (1959)methods. The cellulose, hemicelluloses and lignin content were determined according to Arunakumara et al., methods(2013). The carbonate and bicarbonate $\left(\mathrm{CO}_{3}{ }^{=}, \mathrm{HCO}_{3}{ }^{-}\right)$, chlorosity $\left(\mathrm{Cl}^{-}\right)$, sulphate $\left(\mathrm{SO}_{4}{ }^{-}\right)$, calcium $\left(\mathrm{Ca}^{+2}\right)$, magnesium $\left(\mathrm{Mg}^{+2}\right)$, sodium and potassium $\left(\mathrm{Na}^{+}, \mathrm{K}^{+}\right)$and ammonium $\left(\mathrm{NH}^{+4}\right)$ according to APHA, (1992). The nitrate $\left(\mathrm{NO}_{3}{ }^{-}\right)$was determined according to Mullin and Riley (1955) methods. The concentration of carbonates and sodium adsorption ratio were determined according an experimental parameter by Muhammad and Saqib (2014).

Removing heavy metals by using activated carbons:-
Different adsorbent weights of prepared activated carbons from orange peel, banana peel and leave of date trees with different amounts of each one (0.4, $0.8,1.2,1.6$ and $2 \mathrm{~g}$ ) were mixed with $40 \mathrm{ml}$ wastewater and were shak at $150 \mathrm{rpm}$ for $3 \mathrm{~h}$ at $30^{\circ} \mathrm{C}$. Thewastewater were taken from different sources. The concentrations of each heavy metal such as nickel, copper, zinc, lead, cobalt and cadmium were determined by using atomic adsorption spectrophotometer, model 2038. The absorbed values of the different studied heavy metals ions were calculated according to Sugumasanet al.,methods (2012).

\section{Results and Discussion}

\section{Chemical composition of agricultural food wastes} under investigation:-

The biochemical analysis results of orange peel, banana peel and leave of date trees are presented in Table (1). From the obtained data the proximate analysis, such as moisture and ash content were high in orange peel $(10.12 \pm 0.18 \mathrm{~g} / 100 \mathrm{~g})$ and banana peel $(9.08 \pm 0.17 \mathrm{~g} / 100 \mathrm{~g})$ but banana peel content high crude fat $(6.30 \pm 0.05 \mathrm{~g} / 100 \mathrm{~g})$. While, the crude protein was found high in leave of date trees $(8.26 \pm 0.60 \mathrm{~g} / 100 \mathrm{~g}) . \mathrm{On}$ the other hand, the carbohydrate content of different agro-wastes under investigation was found to be $58.10 \pm 0.10$, $42.20 \pm 0.10$ and $46.32 \pm 0.10 \mathrm{~g} / 100$ gfor orange peel, bananas peel and leave of date trees, respectively. These results are in agreement with those reported by Kamsonlian et al., (2011) and Sugumaran et al., (2012). Also, the cellulose, hemicelluloses and lignin contents were found to be $14.28 \pm 0.49,4.10 \pm 0.49$ and $4.15 \pm 0.12 \mathrm{~g} / 100 \mathrm{~g}$ for orange peel, while, these values were $12.60 \pm 0.49,9.20 \pm 0.49$ and $8.32 \pm 0.12$ $\mathrm{g} / 100 \mathrm{~g}$ for banana peel. But the mean values were found to be $17.20 \pm 0.49,9.42 \pm 0.49$ and $1.53 \pm 0.12$ $\mathrm{g} / 100 \mathrm{~g}$ for leave of date trees, respectively. Although, the obtained results are closed to those reported by Budinovaet al., (2006), Hossainet al., (2012) andSugumaran et al., (2012). They obtained about similar results. 
Table 1. Chemical composition of agricultural food wastes $(\mathrm{g} \backslash 100 \mathrm{~g})$ on the dry weight basis

\begin{tabular}{cccc}
\hline Components & \multicolumn{3}{c}{ Lignocelluloses wastes (wt \% dry basis) } \\
\cline { 2 - 4 } & Orange peel & Banana peel & leave of date trees \\
\hline Moisture & $10.12^{\mathrm{a}} \pm 0.18$ & $5.30^{\mathrm{b}} \pm 0.18$ & $6.10^{\mathrm{a}} \pm 0.18$ \\
Crude ash & $5.10^{\mathrm{c}} \pm 0.17$ & $9.08^{\mathrm{a}} \pm 0.17$ & $7.04^{\mathrm{b}} \pm 0.17$ \\
Crude fat & $2.15^{\mathrm{c}} \pm 0.05$ & $6.30^{\mathrm{a}} \pm 0.05$ & $4.13^{\mathrm{b}} \pm 0.05$ \\
Crude protein & $2.00^{\mathrm{b}} \pm 0.60$ & $7.00^{\mathrm{b}} \pm 0.60$ & $8.26^{\mathrm{a}} \pm 0.60$ \\
Carbohydrate & $58.10^{\mathrm{a}} \pm 0.10$ & $42.20^{\mathrm{b}} \pm 0.10$ & $46.32^{\mathrm{a}} \pm 0.10$ \\
Cellulose & $14.28^{\mathrm{b}} \pm 0.49$ & $12.60^{\mathrm{b}} \pm 0.49$ & $17.20^{\mathrm{a}} \pm 0.49$ \\
Hemicelluloses & $4.10^{\mathrm{b}} \pm 0.49$ & $9.20^{\mathrm{a}} \pm 0.49$ & $9.42^{\mathrm{a}} \pm 0.49$ \\
Lignin & $4.15^{\mathrm{b}} \pm 0.12$ & $8.32^{\mathrm{a}} \pm 0.12$ & $1.53^{\mathrm{c}} \pm 0.12$ \\
\hline
\end{tabular}

Values are mean \pm standard deviation of three replicates

\section{Physical and chemical parameters of wastewater} under investigation:-

The physical properties such as color, odor,turbidity, transparency and $\mathrm{pH}$ for different sources of wastewater before and after filtration by various plant by products are summarized in Table (2). Industrial wastewater under investigation (Mubarak
Zone region- Quesna) before and after treatment in the industrial station were evaluated. The obtained results for color, odor, turbidity and transparency were found to be muddy, disagreeable and turbid, respectively before filtrationalso, but after filtration these parameters were found to be clear, agreeably and clear, respectively.

Table (2): Evaluation the physical parameters of industrial wastewater before and after treatments

\begin{tabular}{ccccc}
\hline \multirow{2}{*}{ Parameters } & \multicolumn{4}{c}{ Industrial wastewater } \\
\cline { 2 - 5 } & \multicolumn{2}{c}{ Before treatment } & \multicolumn{2}{c}{ After treatment } \\
\cline { 2 - 5 } & Before filtration & After filtration & Before filtration & After filtration \\
\hline Color & Muddy & Clear & Muddy & Clear \\
\hline Odor & Disagreeable & Agreeable & Disagreeable & Agreeable \\
\hline Turbidity & Turbid & Clear & Turbid & Clear \\
\hline Transparency & Turbid & Clear & Turbid & Clear \\
\hline
\end{tabular}

Also, the chemical characterization of the above all samples from different sources were evaluation i.e. electrical conductivity, (E.C.) soluble anions $\left(\mathrm{CO}_{3}{ }^{2}\right.$, $\left.\mathrm{HCO}_{3}{ }^{-}, \mathrm{Cl}^{-}, \mathrm{SO}_{4}{ }^{-}\right)$, soluble cations $\left(\mathrm{Ca}^{+2}, \mathrm{Mg}^{+2}, \mathrm{Na}^{+}\right.$and $\mathrm{K}^{+}$), residual sodium carbonate (RSC), and sodium adsorption ratio (SAR) as well as concentration of $\mathrm{NH}^{+4}$ and $\mathrm{NO}_{3}{ }^{-}$. The obtained data are recorded in Table (3). From the obtained results, the electrical conductivity of industrial wastewater from different source samples was higher than $(3.44,14.77 \mathrm{ds} / \mathrm{m})$. Also, soluble anions such as $\mathrm{CO}_{3}{ }^{\circ}, \mathrm{HCO}_{3}{ }^{-}, \mathrm{Cl}^{-}$and $\mathrm{SO}_{4}=$ were estimated for different water samples under investigation. The mean values of soluble anions, $\mathrm{CO}_{3}=\mathrm{HCO}_{3}{ }^{-}, \mathrm{Cl}^{-}$and $\mathrm{SO}_{4}{ }^{=}$were found to be $0.00,4.06$, 11.92 and $11.90 \mathrm{meq} / \mathrm{L}$ for Mubarak Zone region industrial wastewater before treatment, respectively. While, these values of the other samples after treatment were $0.00,13.87,44.58$ and $43.20 \mathrm{meq} / \mathrm{L}$ for soluble anion, respectively. Also, Tables (3) illustrated the soluble cations such as $\mathrm{Ca}^{+2}, \mathrm{Mg}^{+2}, \mathrm{Na}^{+}$and $\mathrm{K}^{+}$, residual sodium carbonate (RSA) and soluble adsorption ratio (SAR). The mean values of these cations were found to be treatment 7.14, 2.32, 18.26, $0.15,0.00$ and $8.40 \mathrm{meq} / \mathrm{L}$ for industrial wastewater after treatment, respectively. While, these values were
$10.00,1.38,90.00,0.28,0.00$ and $37.73 \mathrm{meq} / \mathrm{L}$ for industrial wastewater before treatment, respectively. While, $\mathrm{NH}_{4}{ }^{+}$and $\mathrm{NO}_{3}{ }^{-}$contents were found to be 5.11 and $15.89 \mathrm{mg} / \mathrm{Lfor}$ industrial wastewater after treatment and were found to be 8.40 and $10.85 \mathrm{mg} / \mathrm{Lfor}$ industrial wastewater entrance of the treatment plant and factories leather waste and food, respectively. These results are in agreement of those reported by Castro et al., (2011), Sugumaran et al., (2012) and Majumdar et al., (2016).

\section{Production of active carbons:-}

Date in Table (4) illustrated the production of active carbons from different sources of lignocelluloses food wastes at $450^{\circ} \mathrm{C}$. From the obtained results, it can be observed that the leaves of date trees produced the highest yield of active carbon equaled to $49.28 \%$ and $78.86 \%$ at different activation of food wastes $\mathrm{KOH}$ and $\mathrm{H}_{3} \mathrm{PO}_{4}$ respectively, in compassion compared with other agro-wastes and other activation methods. On the other hand, the yield of $35.89 \%$ was recorded in banana peel treated with $\mathrm{H}_{3} \mathrm{PO}_{4}$ followed by the treatment with $\mathrm{KOH} 25.30 \%$ in compassion with distilled wastes $25.30 \%$ as activation method (untreated). The yield of $38.49 \%$ was recorded in orange peel treated with 
$\mathrm{H}_{3} \mathrm{PO}_{4}$ and $\mathrm{KOH}$ respectively. These results are in accordance with those reported by Sugumaran $\boldsymbol{e t}$ al., (2012).

Initial concentrations of some heavy metals of industrial wastewater before treatment:-

The present investigation was curried out evaluate the removal of metals and heavy metals such as $\mathrm{Ni}^{+2}, \mathrm{Cu}^{+2}$, $\mathrm{Zn}^{+2}, \mathrm{~Pb}^{+2}, \mathrm{CO}^{+2}$ and $\mathrm{Cd}^{+2}$. The samples under investigation were taken from industrial Mubarak Zone, Monofeya. The obtained results are recorded in
Table (5). From the above-mentioned data, it can conclude that the initial concentration of the studied heavy metals like $\mathrm{Ni}^{+2}, \mathrm{~Pb}^{+2}$ and $\mathrm{CO}^{+2}$ in wastewater were higher than the permissible leaves according to WHO,(2006). While, the other heavy metals such as $\mathrm{Zn}^{+2}, \mathrm{Cu}^{+2}$ and $\mathrm{Cd}^{+2}$ were lower than the permissible levels. These results are in agreement with those reported by Shaet al., (2010), Shaba et al., (2014) and Manjuladevi et al., (2017).They reported the some treed by the treatment.

Table 3. Chemical analysis of industrial wastewater

\begin{tabular}{ccc}
\hline Measurements & Entrance of the treatment plant & Factories leather waste and food \\
\hline $\mathbf{E C}(\mathbf{d s} / \mathbf{m})$ & 3.44 & 14.77 \\
\hline $\mathbf{p H}$ & 7.50 & 7.90 \\
\hline $\mathbf{C O}^{-}$ & Soluble Anions (meq./L) & 0.00 \\
\hline $\mathbf{H C O}^{-}$ & 0.00 & 13.87 \\
\hline $\mathbf{C l}^{-}$ & 4.06 & 44.58 \\
\hline $\mathbf{S O}^{-}$ & 11.92 & 43.20 \\
\hline & 11.90 & 10.00 \\
\hline $\mathbf{C a}^{++}$ & Soluble cations (meq./L) \\
\hline $\mathbf{M g}^{++}$ & 7.14 & 1.38 \\
\hline $\mathbf{N a}^{+}$ & 2.32 & 90.00 \\
\hline $\mathbf{K}^{+}$ & 18.26 & 0.28 \\
\hline $\mathbf{R S C}_{\mathbf{S A R}}$ & 0.15 & 0.00 \\
\hline $\mathbf{N H}^{+}$ & 0.00 & 37.73 \\
\hline $\mathbf{N O}^{-}$ & 8.40 & 8.40 \\
\hline & $\mathbf{C o n c e n t r a t i o n}(\mathbf{m g} / \mathbf{L})$ & 10.85 \\
\hline
\end{tabular}

Table 4. Activated carbons of agricultural food wastes at different activation methods

\begin{tabular}{cccc}
\hline $\begin{array}{c}\text { Agricultural food wastes } \\
\text { samples }\end{array}$ & \multicolumn{3}{c}{ Activated carbons (\%) } \\
\cline { 2 - 4 } & $\mathbf{K O H ~ ( 1 0 \% )}$ & Activation methods \\
\cline { 2 - 4 } & 22.30 & $\mathbf{H}_{\mathbf{3}} \mathbf{P O} \mathbf{4}(\mathbf{1 0} \%)$ & Untreated distilled water \\
\hline Orange peel & 25.30 & 38.49 & 15.21 \\
\hline Banana peel & 49.28 & 35.89 & 25.05 \\
\hline Leave of date trees & & 78.86 & 49.20 \\
\hline
\end{tabular}

Table 5. Initial concentrations of some heavy metals of industrial wastewater

\begin{tabular}{|c|c|c|c|}
\hline \multirow[t]{3}{*}{ Metal ions } & \multirow{3}{*}{$\begin{array}{l}\text { permissible levels } \\
(\mathrm{mg} / \mathrm{L}) \text { according to } \\
(\mathrm{WHO}, 2006)\end{array}$} & \multicolumn{2}{|c|}{ Heavy metal concentrations (mg\L) } \\
\hline & & \multicolumn{2}{|c|}{ Industrial Mubarak ZoneMonofeya } \\
\hline & & Before & After \\
\hline $\mathrm{Ni}^{+2}$ & 0.01 & $3.81 \pm 0.01$ & $1.81 \pm 0.01$ \\
\hline $\mathrm{Cu}^{+2}$ & 1.00 & 0.00 & 0.00 \\
\hline $\mathrm{Zn}^{+2}$ & 1.00 & $0.13 \pm 0.01$ & $0.19 \pm 0.01$ \\
\hline $\mathrm{Pb}^{+2}$ & 0.05 & $0.81 \pm 0.01$ & $0.72 \pm 0.01$ \\
\hline $\mathrm{CO}^{+2}$ & 0.05 & $0.85 \pm 0.01$ & $0.80 \pm 0.01$ \\
\hline $\mathrm{Cd}^{+2}$ & 0.05 & 0.00 & 0.00 \\
\hline
\end{tabular}

Effect of active carbons from different agricultural food wastes on the removal of heavy metals from industrial wastewater:-
The effect of producing active carbons from different agro-food wastes on the removal of nickel $\left(\mathrm{Ni}^{+2}\right)$ in wastewater before and after treatment was 
evaluated and the obtained results are recorded in Table (6). From these results, it can be generally noticed that the removal percentages of $\mathrm{Ni}^{+2}$ ion under different activation methods $\left(\mathrm{KOH}\right.$ and $\left.\mathrm{H}_{3} \mathrm{PO}_{4}\right)$ from wastewater were increased with increasing the adsorbent dosage of the active carbons. In case of productive carbons under activation method by $\mathrm{KOH}$, maximum removal percentage of nickel $\left(\mathrm{Ni}^{+2}\right)$ was found to $9.97 \%$ for orange peel with maximum dose $(2 \mathrm{~g})$. But, with banana peel were significantly higher which equaled $(37.80 \%)$. However, the highest level of removal percentage of $\mathrm{Ni}^{+2}$ in the case of active carbons produced from leaves of date trees by activation method with $\mathrm{KOH}$ which was $45.67 \%$, at the same dose $(2.0 \mathrm{~g})$ of bioadsorbent. These results are slightly different with those reported by Morenopiraján and Giraldo (2012).

Also, the removal of zinc $\left(\mathrm{Zn}^{+2}\right)$ from wastewater before the treatment was estimated and the obtained results are presented in Table (7). Under activation methods by $\mathrm{KOH}, \mathrm{H}_{3} \mathrm{PO}_{4}$ orange peel, banana peel and leave of date trees, removal percentage of zinc $\left(\mathrm{Zn}^{+2}\right)$ was found to be $100.00 \%$ at dose of $2.0 \mathrm{~g}$. However, the removal percentage of $\mathrm{Zn}^{+2}$ in the case of activated carbons produced from the above-mentioned food wastes by activation method with $\mathrm{KOH} 100.00 \%$ under the same dose $(1.6 \mathrm{~g})$ of bioadsorbent. The obtained results are close with that reported by Ashraf et al., (2011)This peculiar nature of nickel indicates relatively higher variation in oxidation states (d8 element), in contrast to zinc (d10 element) Rasheed et al., (2013).

The adsorption efficiency of agro-wastes on the removal of $\mathrm{pb}^{+2}$ ion in wastewater from Mubarak Zone region- Quesna before treatments are presented in Table (8). From the obtained results, maximum removal percentage of lead $\left(\mathrm{Pb}^{+2}\right)$ was found to be $34.57 \%$ in case of activation method by $\mathrm{KOH}$ from orange peel. But, with banana peel was significantly higher, which found to be $79.01 \%$ at same doses of biosorbent $2.0 \mathrm{~g}$. However, the highest level of removal percentage of $\mathrm{Pb}^{+2}$ in the case of activated carbons produced from leave of date trees by activation method with $\mathrm{KOH}$ was $88.89 \%$ at dose $(2.0 \mathrm{~g})$ of bioadsorbent. The obtained results are different with those reported by Azizi and Ghasmeni (2015).

While, the effect of producing active carbons from different agro-food wastes in the removal of cobalt $\left(\mathrm{Co}^{+2}\right)$ in wastewater before pretreatment was evaluated and the results are recorded in Table (9).In case of activation method by $\mathrm{KOH}$ from orange peel, maximum removal percentage of cobalt $\left(\mathrm{Co}^{+2}\right)$ equaled to $44.71 \%$, but with banana peel the vole significantly higher where it has been found to be $(76.47 \%)$ at adsorbent weight of dose $2.0 \mathrm{~g}$. However, removal percentage of $\mathrm{Co}^{+2}$ reached to $96.47 \%$ at the same dose $(2.0 \mathrm{~g})$ of bioadsorbent in the case of active carbons produced from leaves of date trees by activation method with $\mathrm{KOH}$. The obtained results are in agreement with those reported byRengeet al., (2012) who found about similar results.

Data in Table (10) show the effect of biosorbent produced active carbons from different agro-food wastes in the removal of nickel $\left(\mathrm{Ni}^{+2}\right)$ in wastewater. The maximum removal percentage of nickel $\left(\mathrm{Ni}^{+2}\right)$ was found to $48.07 \%$ in case of orange peel, but with leaves of date trees, were significantly lower $(43.65 \%)$ at same maximum dose $(2.0 \mathrm{~g})$. However, the highest removal percentage of $\mathrm{Ni}^{+2}$ in the case of activated carbons produced from banana peel by activation method with $\mathrm{KOH}$ which was $51.38 \%$ at the same dose $(2.0 \mathrm{~g})$ of bioadsorbent. The obtained results are different with those reported by Annadusaiet al., (2017)..Fanatical groups most commonly implicated in such interactions include carboxylate, hydroxyl, amine and phosphoryl groups present within cell wall components such as polysaccharides, lipids and proteinsOzeret al., (2004).

Also, the effect of produced active carbons from differentagro-food wastes on the removal percentage of zinc $\left(\mathrm{Zn}^{+2}\right)$ of wastewater after the treatmentwas evaluated and the obtained results are recorded in Table (11), by using the active carbons of orange peel, banana peel and leave of date trees. From the obtained data the maximum removal percentage of zinc $\left(\mathrm{Zn}^{+2}\right)$ was found to $100.00 \%$ as biosorbent at $2.0 \mathrm{~g}$ expect leave of date trees with activation method by $\mathrm{H}_{3} \mathrm{PO}_{4}(89.47 \%)$.However, the highest level of removal percentage of $\mathrm{Zn}^{+2}$ in the case of activated carbons produced from different agricultural food wastes under investigation by activation method with $\mathrm{KOH}$ was $100.00 \%$ at the same dose $(2.0 \mathrm{~g})$ of bioadsorbent . The achieved results are in agreement with those reported by Rengeet al., (2012) reported about the same trend.

The removal of lead $\left(\mathrm{Pb}^{+2}\right)$ from wastewater by the above-mentionedsamples after the treatment by adsorption processes was evaluated and the obtained results are recorded in Table (12). From these data, it can be observed that the maximum removal percentage of lead $\left(\mathrm{Pb}^{+2}\right)$ was found to be $79.17 \%$ for orange peel. But with banana peel, this value was significantly higher $(87.50 \%)$ at some doses $2.0 \mathrm{~g}$. In the case of activecarbons produced from leave of date trees by activation method with $\mathrm{KOH}$, the removal was percentage $88.89 \%$ at the same dose $(2.0 \mathrm{~g})$ of bioadsorbent. The obtained results are in agreement with those reported by Manjuladevi and Oviuaa (2017) who observed about the same observation.

But, the effect of active carbons from different agro-food wastes in the removal of cobalt $\left(\mathrm{Co}^{+2}\right)$ in wastewater after pretreatment was evaluated. The obtained results are recorded in Table (13). 
Table (6): Effect of activae carbons from different agricultural food wastes on the removal of metal $\left(\mathrm{Ni}^{+2}\right)$ ion from industrial wastewater before treatment

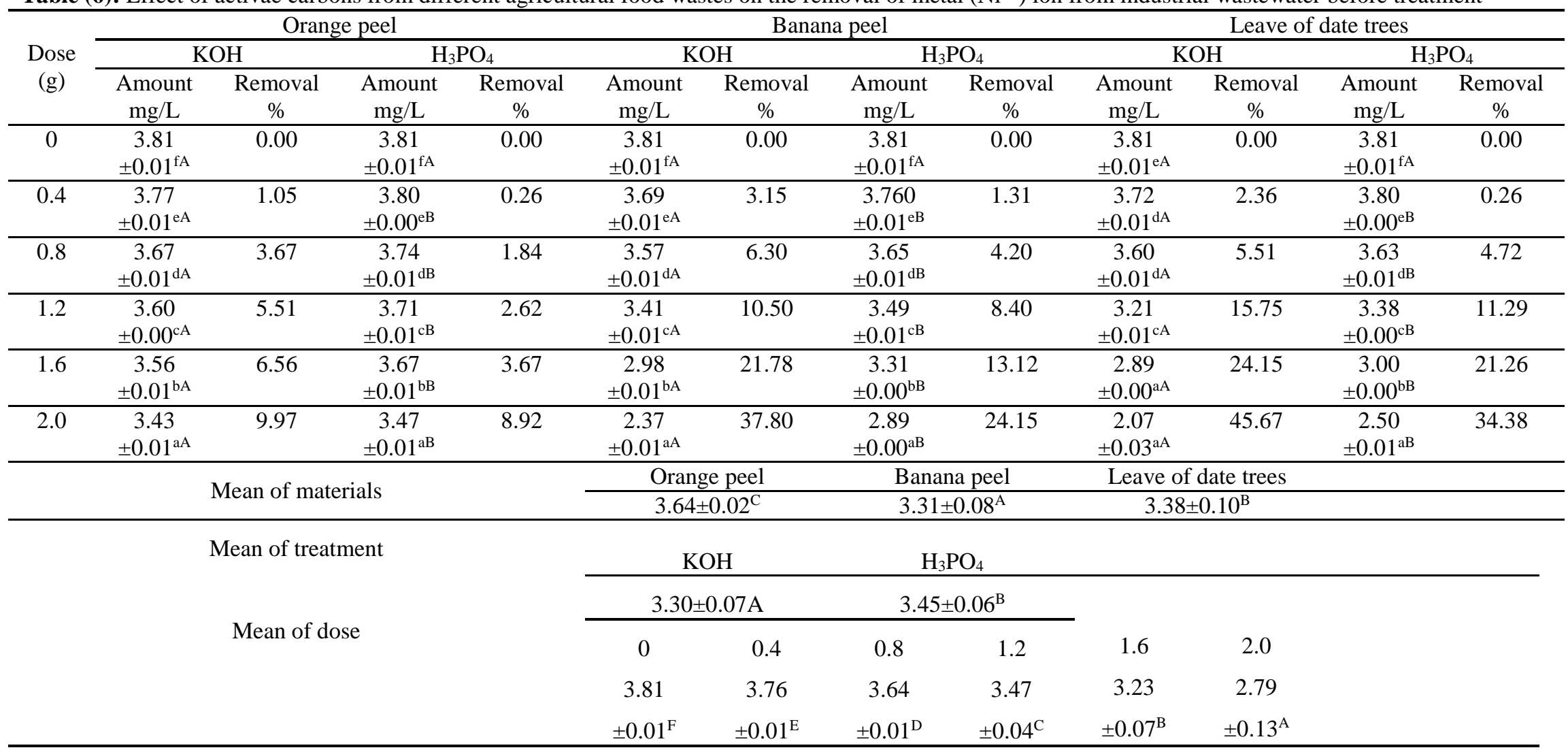

a, b \& c: There is no significant difference $(\mathrm{P}>0.05)$ between any two means, within the same column have the same superscript letter.

A, B \& C: There is no significant difference $(\mathrm{P}>0.05)$ between any two means for the same attribute, within the same row have the same superscript letter. 
Table 7. Effect of active carbons from different agricultural food wastes on the removal of heavy metal $\left(\mathrm{Zn}^{+2}\right)$ ion from industrial wastewater before treatment

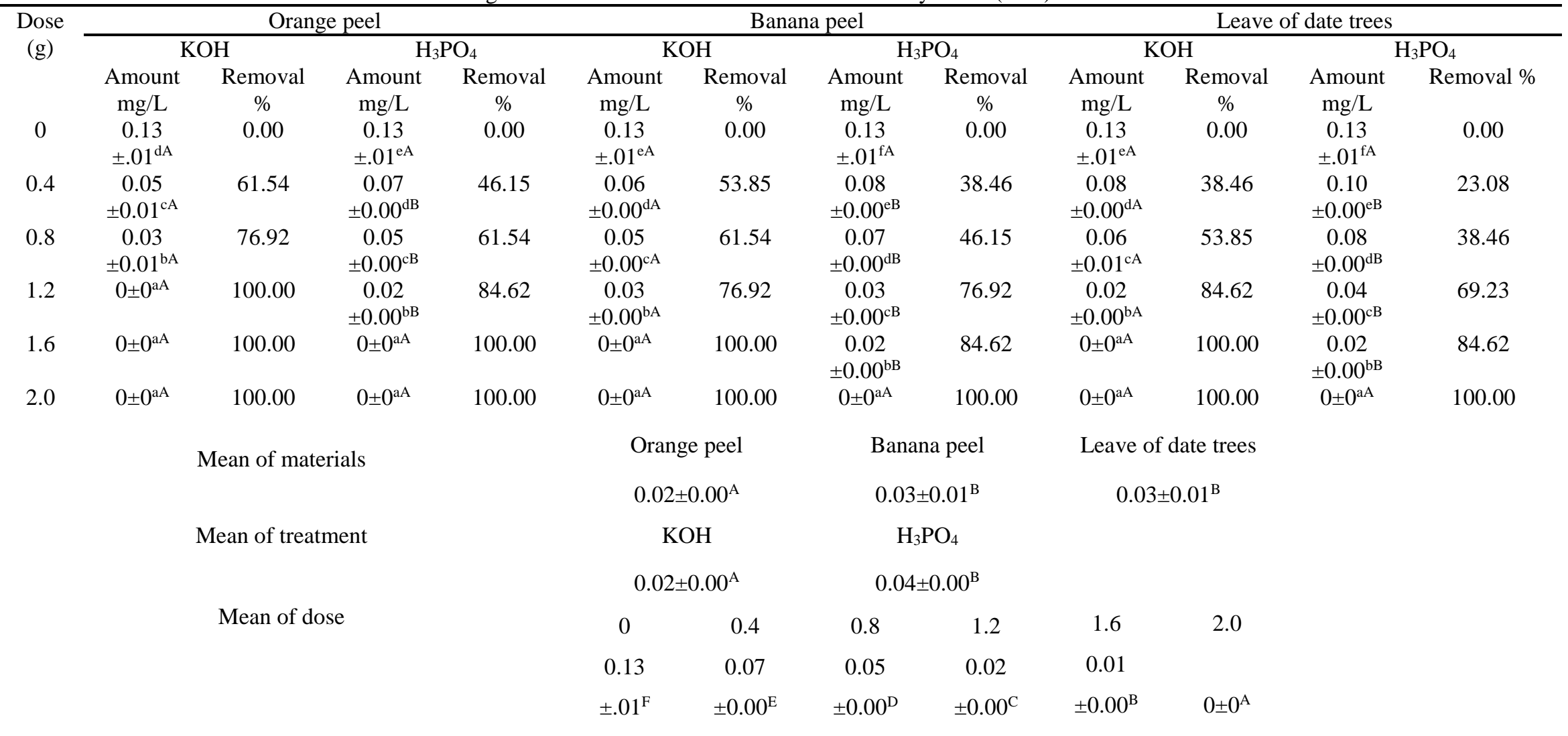

a, b \& c: There is no significant difference ( $\mathrm{P}>0.05)$ between any two means, within the same column have the same superscript letter.

A, B \& C: There is no significant difference $(\mathrm{P}>0.05)$ between any two means for the same attribute, within the same row have the same superscript letter. 
Table 8. Effect of active carbons from different agricultural food wastes on the removal of heavy metal $\left(\mathrm{Pb}^{+2}\right)$ ion from industrial wastewater before treatment

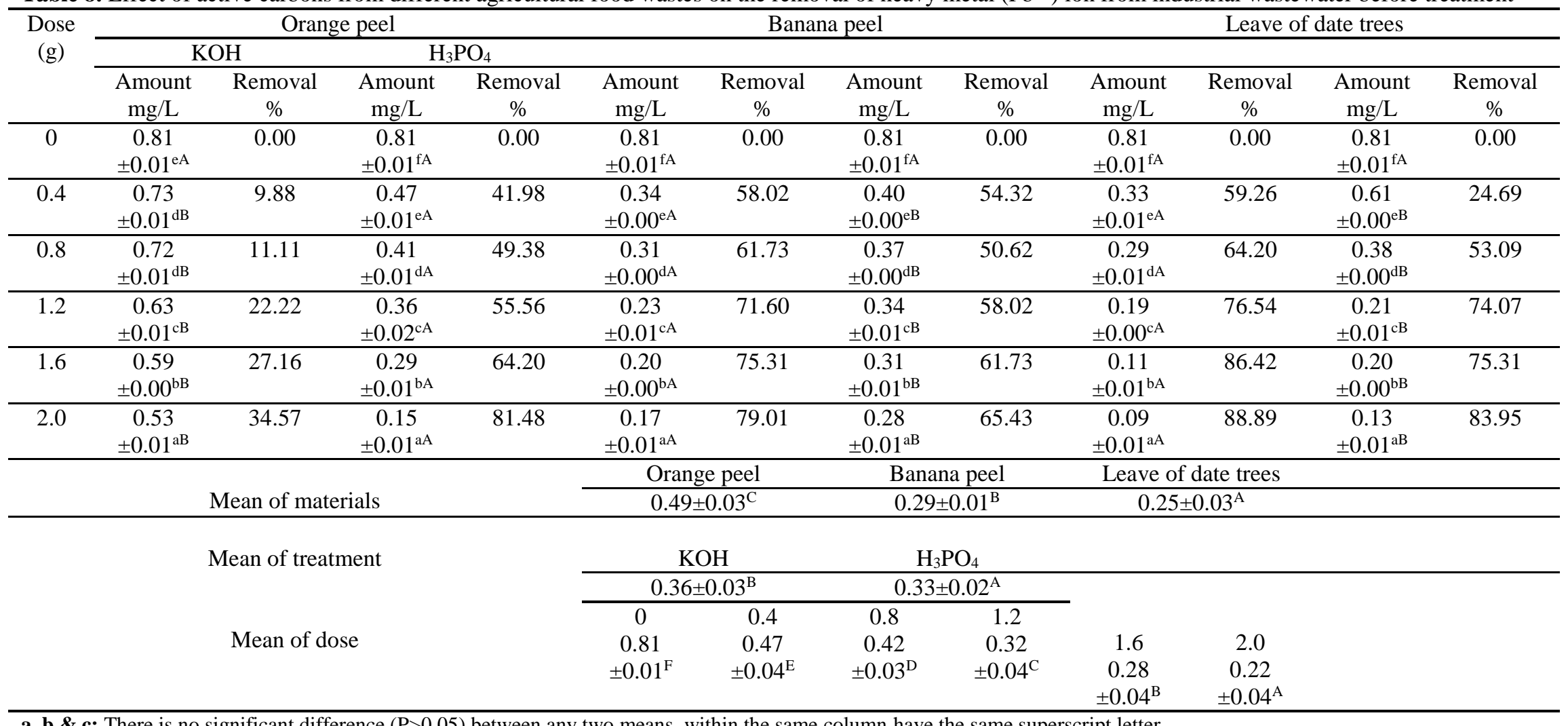

a, b \& c: There is no significant difference $(\mathrm{P}>0.05)$ between any two means, within the same column have the same superscript letter.

A, B \& C: There is no significant difference $(\mathrm{P}>0.05)$ between any two means for the same attribute, within the same row have the same superscript letter. 
Table (9): Effect of active carbons from different agricultural food wastes on the removal of heavy metal $\left(\mathrm{Co}^{+2}\right)$ ion from industrial wastewater before treatment

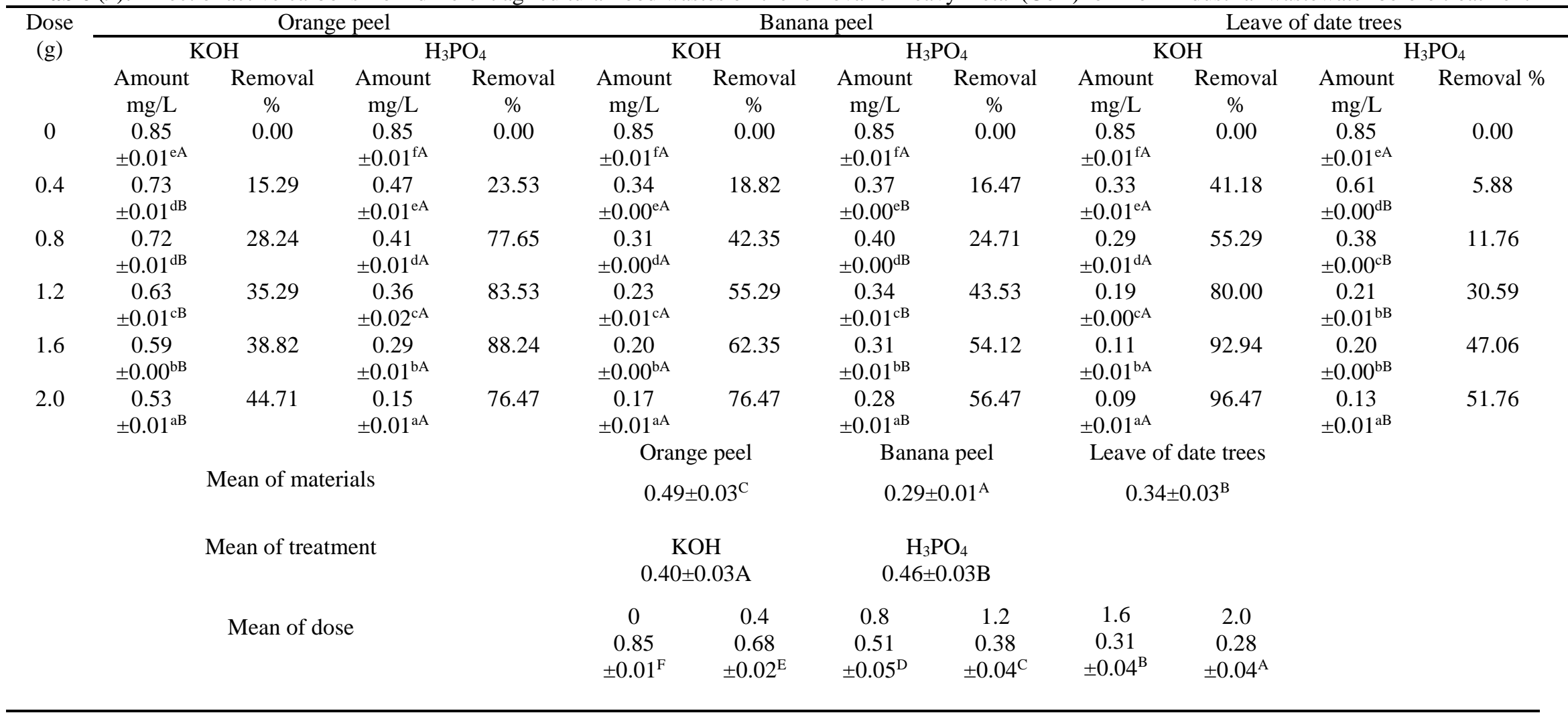

a, b \& c: There is no significant difference $(\mathrm{P}>0.05)$ between any two means, within the same column have the same superscript letter.

A, B \& C: There is no significant difference $(\mathrm{P}>0.05)$ between any two means for the same attribute, within the same row have the same superscript letter. 
Table (10) Effect of active carbons from different agricultural food wastes on the removal heavy metal $\left(\mathrm{Ni}^{+2}\right)$ ion from industrial wastewater after treatment

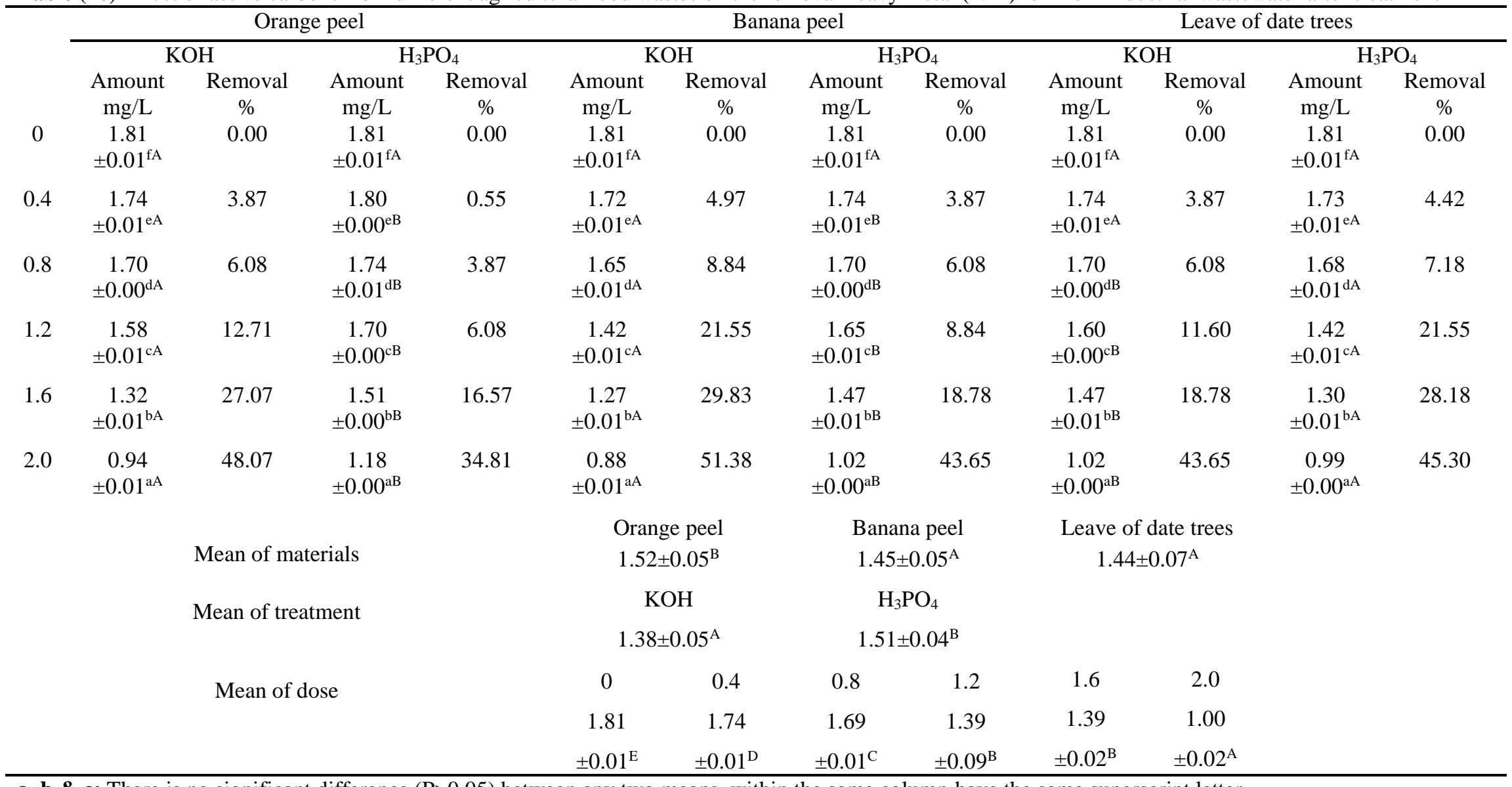

a, b \& c: There is no significant difference ( $\mathrm{P}>0.05)$ between any two means, within the same column have the same superscript letter.

A, B \& C: There is no significant difference $(\mathrm{P}>0.05)$ between any two means for the same attribute, within the same row have the same superscript letter. 
Table (11): Effect of active carbons from different agricultural food wastes on the removal of heavy metal $\left(\mathrm{Zn}^{+2}\right)$ ion from industrial wastewater after treatment

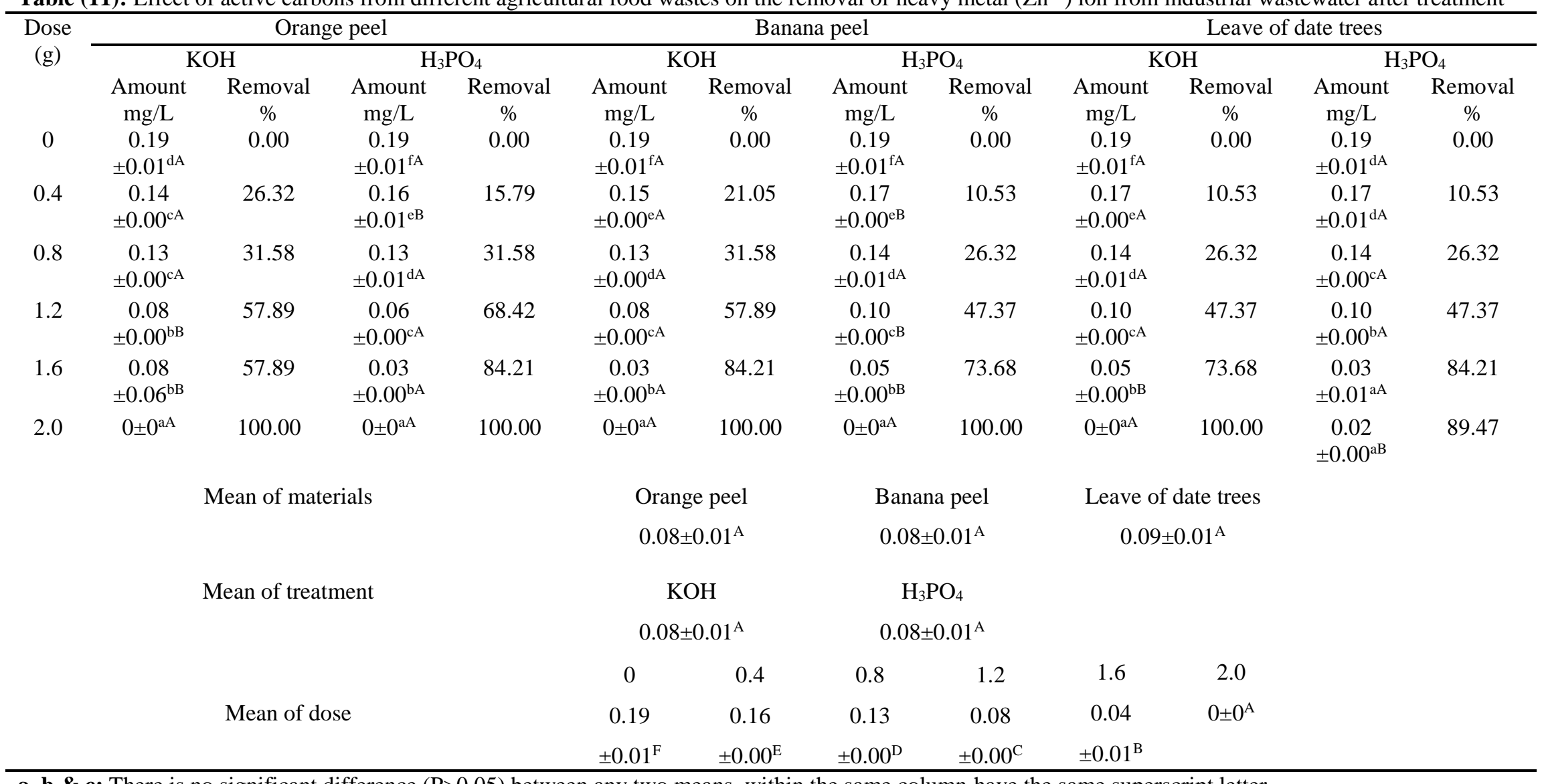

a, b \& c: There is no significant difference $(\mathrm{P}>0.05)$ between any two means, within the same column have the same superscript letter.

A, B \& C: There is no significant difference $(\mathrm{P}>0.05)$ between any two means for the same attribute, within the same row have the same superscript letter. 
Table (12): Effect of active carbons from different agricultural food wastes on the removal of heavy metal $\left(\mathrm{Pb}^{+2}\right)$ ion from industrial wastewater after treatment

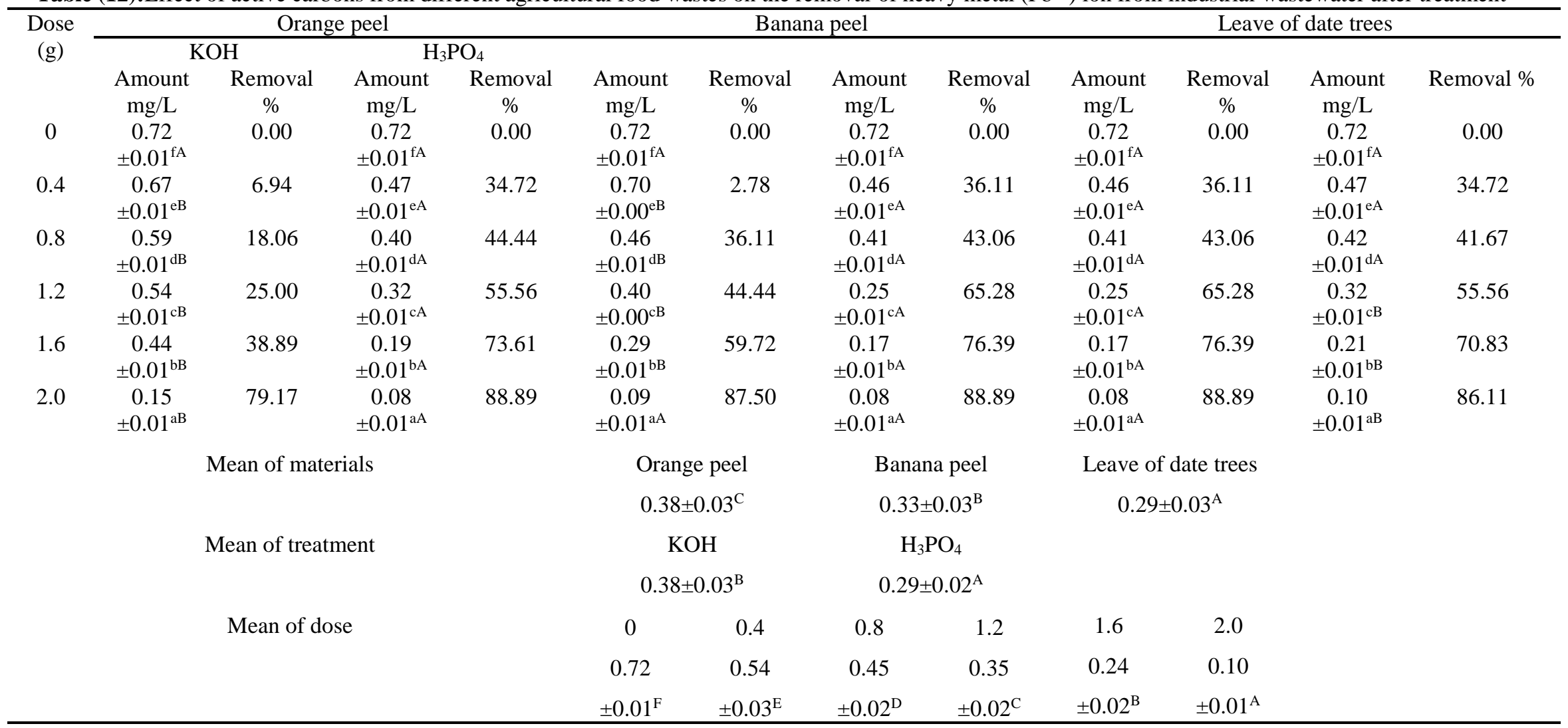

a, b \& c: There is no significant difference $(\mathrm{P}>0.05)$ between any two means, within the same column have the

same superscript letter.

A, B \& C: There is no significant difference $(\mathrm{P}>0.05)$ between any two means for the same attribute, within the same row have the same superscript letter 
Table (13): Effect of active carbons from different agricultural food wastes on the removal of heavy metal $\left(\mathrm{Co}^{+2}\right)$ ion from industrial wastewater after treatment

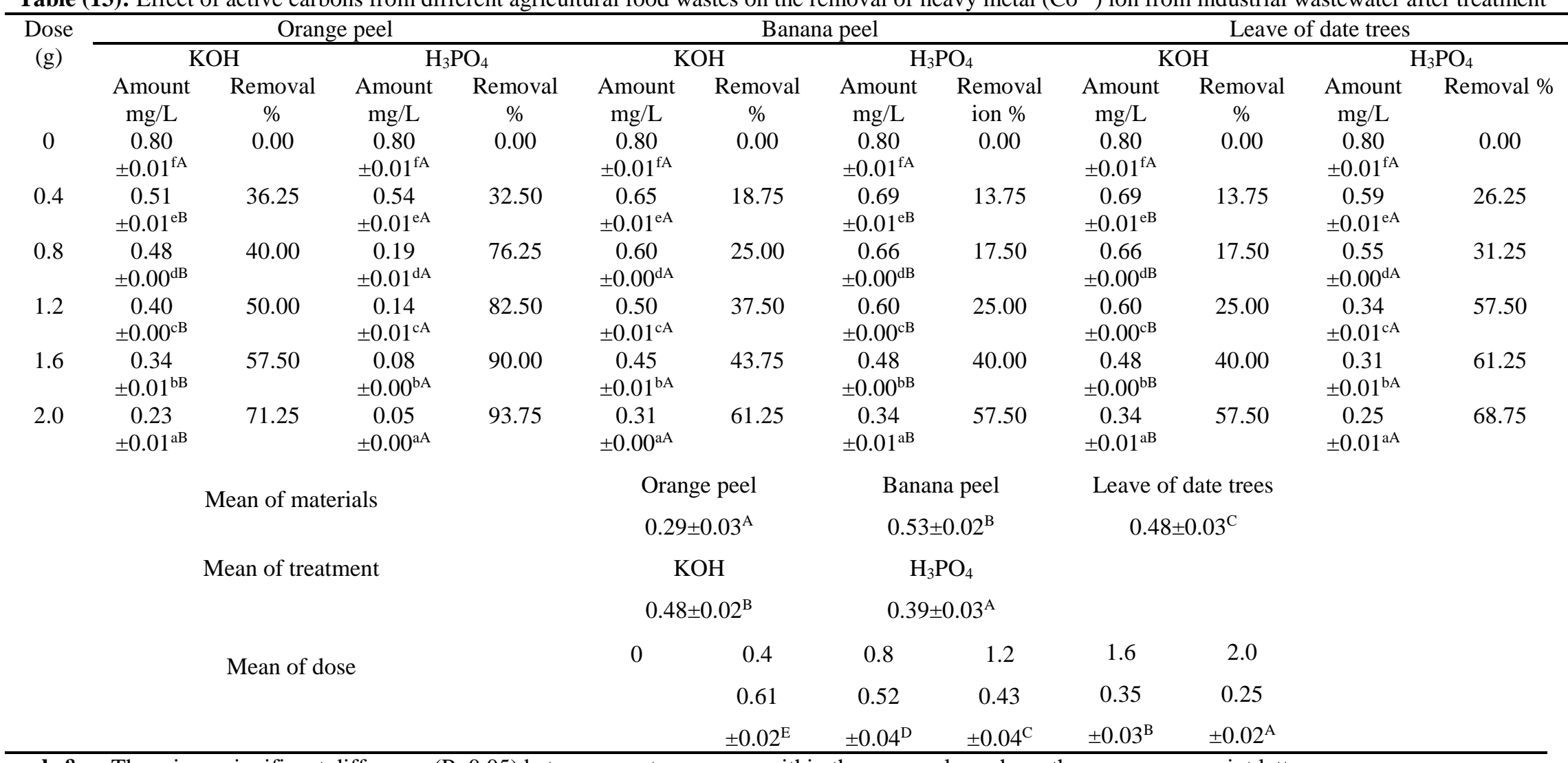

a, b \& c: There is no significant difference $(\mathrm{P}>0.05)$ between any two means, within the same column have the same superscript letter.

A, B \& C: There is no significant difference $(\mathrm{P}>0.05)$ between any two means for the same attribute, within the same row have the same superscript letter 
The removal of cobalt $\left(\mathrm{Co}^{+2}\right)$ was found to $57.50 \%$ for leaves of date trees, but for banana peel, the value was significantly higher where they have been found to be $(61.25 \%)$ at same maximum dose $(2.0 \mathrm{~g})$. However, the highest level of removal percentage of $\mathrm{Co}^{+2}$ observed in the case of active carbons produced from orange peel by activation method with $\mathrm{KOH}$ which was $71.25 \%$ at the same dose $(2.0 \mathrm{~g})$ of bioadsorbent. The accomplished results are slightly different with those reported by Abbasi et al., (2013).

\section{Conclusion}

From the above-mentioned results, it can be concluded that the orange peel, banana peel and leave of date trees, like most other natural absorbents can be used in the treatment process for removal of metals induced heavy metals such as nickel $\left(\mathrm{Ni}^{+2}\right)$, copper $\left(\mathrm{Cu}^{+2}\right)$, zinc $\left(\mathrm{Zn}^{+2}\right)$, lead $\left(\mathrm{pb}^{+2}\right)$, cobalt $\left(\mathrm{CO}^{+2}\right)$ and cadmium $\left(\mathrm{Cd}^{+2}\right)$. The treatment efficiency may be as reached reached to $100 \%$ by choosing the adsorbent amount precisely. Finally, the residues of food wastes can be processed and converted to be adsorbents this is due to theis large surface areas, cheap high swelling capacities, excellent mechanical strengths, and are convenient to use for removal heavy metalsof wastewater.

\section{References}

A.O.A.C. (2010). Official methods of analysis of analytical "19 $19^{\text {th }}$ ED. Association of official analytical chemists, Gaithersburg, Maryland,U.S.A.

Abbasi, Z.; Alikarami, M.; Nezhad, E.R.; Moradi, F. and Moradi V. (2013). Adsorptive removal of $\mathrm{Co}^{+2}$ and $\mathrm{Ni}^{+2}$ by peels of banana from aqueous solution. Universal. J. Chem.,1(3): 90-95.

Achaka, M.; Hafidib, A.; Ouazzania, N.; Sayadic, S. and Mandia, L. (2009). Low cost biosorbent banana peel for the removal of phenolic compounds from olive mill wastewater. J. Hazard. Mater., 166: 117-125.

Amaya, A.; Medero, N.; Tancredi, N.; Silva, H. and Deiana, C. (2007). Activated carbon from biomass materials. Biores. Tech., 98: 1635-1641.

Arunakumara, K.; Walpola, B.C. and Yoon, M.H. (2013). Banana peel a green solution for metal removal from contaminated waters. Korean $\mathrm{J}$. Environ. Agric., 32(2): 108-116.

Annadusai, G.; Juang, R.S. and Lee, D.J.(2017). Adsorption of heavy metals from water using banana and orange peels. Water. Sci.Tech., 47(1): 185-190.

APHA (1992). Standard method for the examination of water and waste, 18th ed., American public health association, washington.
Ashraf, M.A.; Wajid, A.; Mahmood, K. and Maah, M.J. (2011). Low cost biosorbent banana peel ( Musa sapientum ) for the removal of heavy metals. J. Scintific. Res. Essays., 6(19): 40554064.

Azizi, M. and Ghasmeni, N. (2015). Isotherms studies for the removal of $\mathrm{pb}$ (II) from aqueous solutions using by activated carbon prepared from banana peel. Int. J. of Chem and Bio. Sci,. 7: 5256.

Bernfeld, P. (1955). Methods in enzymology. (Acad. press, inc., New York). In s.p. colowick and N.o. Koplan. Eds., 1: 149-154.

Budinova, T.; Ekinci, E.; Yardim, F.; Grimm, A.; Björnbom, E.; Minkova, V. and Goranova, $M$. (2006). Characterization and application of activated carbon produced by $\mathrm{H}_{3} \mathrm{PO}_{4}$ and water vapor activation. Fuel. Process. Tech., 87(10): 899-905.

Castro, R.S.D.; Caetano, L.E.; Ferreira, G.; Padilha, P.M.; Saeki, M.J.; Zara, L.F.; Martines, M.A. and Castro, G.R. (2011). Banana peel applied to the solid phase extraction of copper and lead from river water preconcentration of metal ions with a fruit waste. Ind. Eng. Chem. Res., 50: 3446-3451.

Hossain, M.A.; Ngo, H.H.; Guo, W.S. and Nguyen, T.V. (2012). Removal of copper from water by adsorption onto banana peel as bioadsorbent. Int. J. Geomate., 2(2): 227-234.

Husoon, Z.A.; Al-Azzawi, M.N.A. and Al-Hiyaly, S.A.K. (2013). Investigation biosorption potential of copper and lead from industrial wastewater using orange and lemon peels. J. Al-Nahrain. Univ., 16(2): 173-179.

Jain, N. (2015). Removal of heavy metal by using different fruit peels vegetable peels and organic waste. Int. J. homepage., 3(11): 916-920.

Kamsonlian, S.; Suresh, S.; Majumder, C.B. and Chand, S. (2011). Characterization of banana and orange peels biosorption mechanism . Int. J. Sci. Tech. Manag., 2(4): 2229-6646.

Kulkarni, S.J.; Dhokpande, S.R. and Kaware, J.P.A. (2014). A review on studies on effect of heavy metals on man and environment. Int. J. Sci. Eng. Tech., 2: 227-229.

Lakshmipathy, R.; Sarada, N.C. and Jayaprakash, N. (2015). Agricultural wastes as low cost adsorbents for sequestration of heavy metal ions and synthetic dyes from aqueous solution. Int. J. Chem. Tech. Res., 8(5): 25-31.

Layla, A. and Ahmed, A. (2010). Removal of heavy metals from wastewater by date palm tree wastes. J. Eng. Tech., 28: 119-125.

Li, X.; Tang, Y.; Caoa, X.; Lua, D.; Luo, F. and Shao, W. (2008). Preparation and evaluation of 
orange peel cellulose adsorbents for effective removal of cadmium, zinc, cobalt and nickel colloids and surfaces. Physic. Chem. Eng. Aspects., 317: 512-521.

Majumdar, S.H.; Pimpodkar, N.V. and Ghadge, T.A. (2016). Devising an economical water purification unit using bioadsorbent. J. Basic. Appl., 2(2): 166-170.

Manjuladevi, M. and Oviuaa, Sri. M. (2017). Heavy metals removal from industrial wastewater by nano adsorbent prepared from cucumis melopeel activated carbon. J. Nanomedicine. Res., 5(1): 36.

Miller, G.L. (1959) Use of dinitrosalicylic acid reagent for determination of reducing sugare. Anal. Chem., 31(3): 426-428.

Moreno-piraján, J.C. and Giraldo, L. (2012). Heavy metal ions adsorption from wastewater using activated carbon from orange peel. J. Chem., 9(2): 926-937.

Muhammad. S. and Saqib. N. (2014). Assessment of ground water quality in different areas of Karachi city. J. Chem. Bio. Phy. Sci.,4(4): 948-959.

Mullin, J.B. and Riley, J.P. (1955). The spectrophotometric determination of nitrate in natural waters with particular reference to sea water. Anal. Chem. Acte., 12: 464-480.

Rasheed, A.; Farooq, F. and Rafique, U. (2013). Kinetic study of metal removal using apple peels closed batch approximation model. J. Chem. Envi. Eng., 4(5): 281.
Renge, V.C.; Khedkar, S.V. and Pande, S.V. (2012). Removal of heavy metal from watewater using low cost adsorbents. Sci. Revs. Chem. Commun., 2(4): 580-584.

Sha, L.; Xue-yi, G.; Ning-chuan, F. and Qing-hua, T. (2010). Effective removal of heavy metals from aqueous solutions by orange peel xanthate. Trans. Nonferrous. Met. Soc. China., 20: 187191.

Shaba, E.Y. (2014). Removal of heavy metals from aqueous solutions by modified activated carbon from bombaxbuonopozense. Int. J. Eng. Sci. Invention., 3: 17-24.

Sridhar, N.; Senthilkumar, J.S. and Subburayan, M.R. (2014). Removal of toxic metals (lead and copper) from automotive industry wastewater by using fruit peels. J.ijaict., 1(2): 188-192.

Sugumaran, P.; Susan, V.P.; Ravichandran, P. and Seshadri, S. (2012). Production and characterization of activated carbon from banana empty Fruit bunch and delonix regia fruit Pod. J. Sustain. Energy. Envi., 3: 125-132.

WHO. (2006). Health guidelines for the use of wastewater in agriculture and aquaculture. Report of a WHO Scienitific group, Geneva.

Zuo, S.; Yang, J.; Liu, J. and Cai, X. (2009). Significance of the carbonization of volatile pyrolytic products on the properties of activated carbons from phosphoric acid activation of lignocellulosic material. Fuel. Proce. Tech., 90: 994-1001. 


\section{إزالة أيونات المعادن الثقيلة من مياة الصرف الصناعي بإستخدام المخلفات الزراعية المختلفة

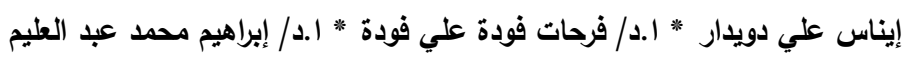 الملخص العزبي}

يعتبر ثلوث المياة من أهم المشاكل التي تسبب الكثير من الأمراض فأغلب المخلفات الصناعية تصرف في النيل دون معالجة مما يسبب

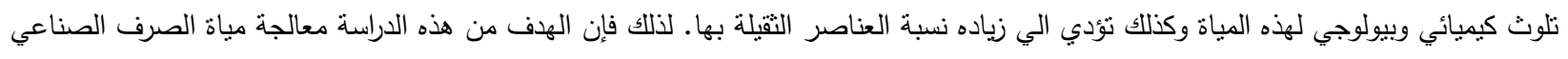

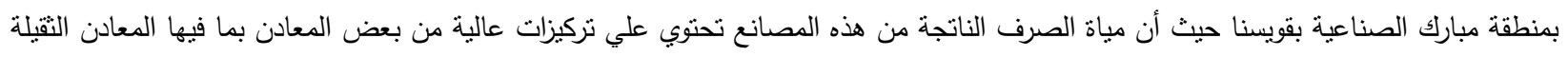

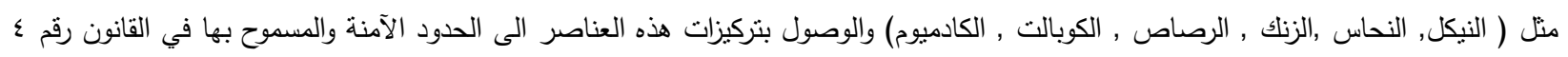

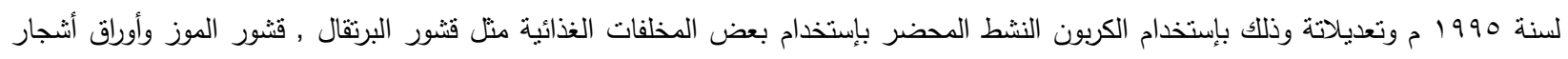

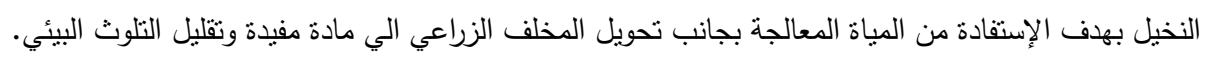

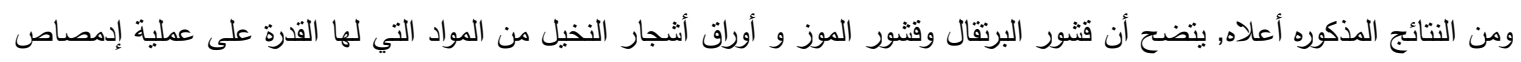

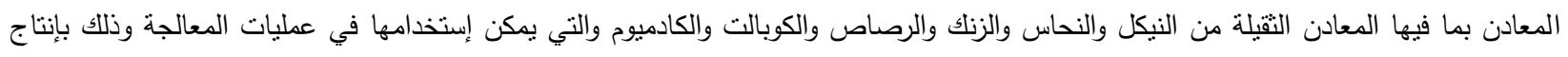

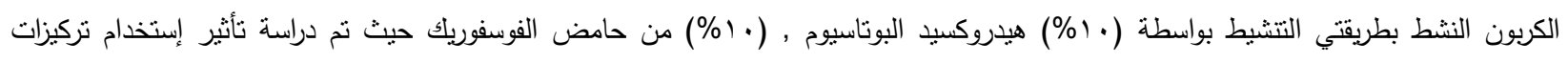

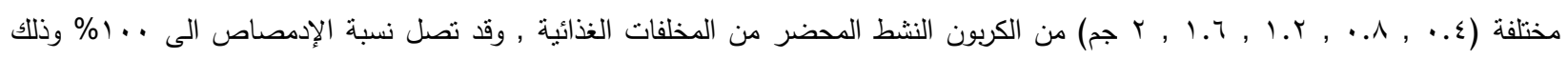
لكفائتها العالية وسهولة إنتخدامها ورخص ثمنها. 